\title{
Centralne procesy przetwarzania słuchowego u dzieci kształconych i niekształconych muzycznie a wyniki w nauce
}

\section{Central auditory processing among musically trained and untrained children and their academic performance}

\author{
Anna Kruczyńska, Zdzisław Marek Kurkowski \\ Zakład Logopedii i Językoznawstwa Stosowanego, Uniwersytet Marii Curie-Skłodowskiej, Lublin
}

Adres autora: Anna Kruczyńska, Uniwersytet Marii Curie-Skłodowskiej, ul. Sowińskiego 17, 20-040 Lublin, e-mail: kruczynska.anna@gmail.com

\section{Streszczenie}

Głównym celem niniejszej pracy jest zbadanie, jak wyższe funkcje słuchowe są rozwinięte w grupie dzieci uczęszczających do szkół muzycznych, w porównaniu z dziećmi niekształconymi muzycznie oraz jak to muzyczne doświadczenie wpływa na wyniki szkolne.

\begin{abstract}
Zakłada się, że muzyczne kształcenie wpływa korzystnie na centralne funkcje słuchowe, a zarazem na osiągane wyniki w nauce szkolnej.

W przeprowadzonych badaniach wzięło udział 50 uczniów szkoły podstawowej w wieku 8-12 lat, uczęszczających do I-V klasy. Podzielono ich na dwie grupy - badawczą stworzoną przez dzieci uczęszczające do szkoły muzycznej I stopnia oraz kontrolną - dzieci nigdy nieuczęszczające do szkoły muzycznej. Na każdą grupę składało się 25 uczniów.
\end{abstract}

\begin{abstract}
W pracy użyto następujących narzędzi badawczych: specjalnie przygotowanej ankiety dla uczniów, testów audiologicznych: testu sekwencji częstotliwości - FPT, testu sekwencji długości - DPT, testu oceniającego rozumienie mowy w hałasie - SPN, a także testu rozdzielnousznego słyszenia ustalającego dominację półkuli w zakresie percepcji dźwięków mowy.
\end{abstract}

Rezultaty przeprowadzonych badań potwierdziły wcześniejsze założenie o lepszych wynikach testów centralnych funkcji słuchowych, uzyskanych przez dzieci kształcone muzycznie w porównaniu z dziećmi bez takiego kształcenia. Największe różnice widoczne były w wynikach testu oceny sekwencji częstotliwości FPT. Trudności w nauce szkolnej napotykały w większej części uczniowie niekształcący się muzycznie. W porównaniu z uczniami zwykłej szkoły, znacznie mniejsza liczba dzieci uczęszczających do szkoły muzycznej miała problemy w nauce takich przedmiotów jak: j.polski, matematyka oraz j.angielski.

Słowa kluczowe: kształcenie muzyczne • centralne funkcje słuchowe • FPT • DPT • SPN • trudności szkolne

Abstract

The main objective of this study is to examine how central auditory functions are developed in the group of children attending schools of music compared with musically untrained children, in addition to musical experience and its impact on school performance. It is assumed that music education has a beneficial effect on central auditory functions, along with the results achieved in school.

The study comprised 50 primary school children aged 8-12 years, attending up to the fifth grade. The subjects were divided into two groups - a research one, consisting of children attending primary schools of music, and a control one, with children never attending any school of music at all. Each group consisted of 25 students.

The study used the following research tools: a specially prepared questionnaires for pupils, audiological tests: Frequency Pattern Test - FPT, Duration Pattern Test - DPT, Speech in Noise - SPN, as well as Dichotic listening test, used as a behavioral test for hemispheric lateralization of speech sound perception. 
The results of the study confirmed the earlier assumption of musically trained children obtaining better results in central auditory functions tests, compared with children without such experience.

The greatest differences were seen in Frequency Pattern Test. Difficulties in regular primary schools were for the most part encountered by the musically untrained pupils. A much smaller number of children attending schools of music had problems while attending courses such as Polish and a second language classes (English in this case) or mathematics.

Key words: music education • central auditory functions $\bullet$ FPT $\bullet$ DPT $\bullet$ SPN • school difficulties

\section{Wstęp}

W obecnych czasach muzyka towarzyszy człowiekowi właściwie na każdym kroku, jest wszechobecna. Wydaje się więc oczywiste, że w pewien sposób musi wpływać na organizm człowieka. Jaki zatem jest jej wpływ? Na to pytanie nie można udzielić jednoznacznej odpowiedzi, chociaż wielu naukowców prowadzi w tym zakresie liczne badania.

Wykonywanie muzyki aktywuje w ludzkim mózgu praktycznie wszystkie znane procesy: percepcję, działanie, reprezentacje społeczne, emocje, uczenie się oraz pamięć. Oznacza to, że proces przetwarzania muzyki jest niezwykle skomplikowany i angażuje się w niego wiele obszarów mózgu [Karwowska, Kudlik 2012].

XX wiek zaowocował rozwojem badań neurologicznych, pozwalając tym samym na dokładną obserwację funkcjonowania mózgu muzyków, a następnie na porównanie jego pracy i anatomii z mózgiem osób nie mających muzycznych doświadczeń [Sacks 2009].

Używając neuroobrazowania stwierdzono znaczne różnice w odbiorze muzyki w przypadku osób z muzycznym wykształceniem. Osoby niekształcone muzycznie, odbierają muzykę głównie prawą półkulą, z kolei u muzyków dodatkowo aktywuje się również obszar lewej półkuli, a jej struktury uczestniczą w przetwarzaniu dźwięku w podobny sposób, jak przetwarzany jest język [Sacks 2009].

Percypowanie muzyki za pomocą prawej półkuli przetwarzane jest jedynie na poziomie prostych wrażeń słuchowych. Charakteryzuje się to przetwarzaniem bodźców emocjonalnych, nie mających ukształtowanego wzorca. Aktywowanie lewej półkuli pobudza struktury uczestniczące przy odbieraniu języka. Dostrzegana jest wówczas składnia, forma oraz reguły rządzące tym przekazem. Dlatego osoby bez wykształcenia muzycznego odbierają muzykę jedynie na podstawowym, konkretno-emocjonalnym poziomie, natomiast posiadające muzyczne doświadczenie już nie tylko odbierają, ale zaczynają ją również rozumieć [Krukow 2003].

Oprócz zmiany lateralizacji, intensywne treningi i ćwiczenia muzyczne przyczyniają się także do innych zmian w strukturze i funkcjonowaniu mózgu.

W celu bliższego poznania anatomicznej charakterystyki mózgu muzyków, prowadzono szereg badań. Z przeprowadzonych badań wykorzystujących morfometrię MRI (obrazowanie rezonansu magnetycznego) wynika, że ciało modzelowate - spoidło łączące dwie półkule mózgu, jest znacznie większe u muzyków niż u niemuzyków. Z kolei równina skroniowa, będąca częścią kory słuchowej, jest asymetrycznie powiększona u muzyków ze słuchem absolutnym. Badacze wykazali także większą ilość substancji szarej, w ruchowej, słuchowej i wzrokowo-przestrzennej części kory mózgowej oraz w móżdżku. Wyraźne są także funkcjonalne zmiany na poziomie pnia mózgu, skutkujące szybszą i silniejszą reakcją na mowę i muzykę. Taka reakcja następuje u tej grupy już po dziesięciu milisekundach od bodźca akustycznego [Sacks 2009].

Nauka gry na instrumencie muzycznym jest jednak procesem długotrwałym i złożonym. Dziecko musi opanować szereg umiejętności m.in. przekładanie zapisu muzycznego na wykonywane ruchy, zapamiętywanie długich partii muzycznych czy identyfikowanie wysokości i barwy dźwięku. Wszystko to wymaga wytężonej pracy umysłowej [Czerniawska 2009].

Rozpoczęcie muzycznego kształcenia związane jest z systematyczną pracą i dobrą organizacją czasu. Kształcenie muzyczne w Polsce obejmuje trzy etapy: szkołę muzyczną I i II stopnia (razem od 8-12 lat) oraz studia wyższe (5 lat). Edukacja w szkołach muzycznych odbywa się najczęściej popołudniami, po dziennych zajęciach w zwykłej szkole. Dzieci podejmują naukę gry na instrumencie (najczęściej na dwóch) i obowiązkowo kształcą się w zakresie historii muzyki, kształcenia słuchu, harmonii, rytmiki i analizy form muzycznych. Na pierwszym etapie nauki mniej czasu poświęca się na ćwiczenia gry na instrumencie, z kolei następne etapy - szkoła muzyczna II stopnia i studia wyższe, kładą ogromny nacisk na intensywne ćwiczenia gry - około 4-8 godzin dziennie. Widać zatem, że muzyczna edukacja stawia swoim uczniom wysokie wymagania, zarówno w zakresie samych umiejętności muzycznych, jak i dodatkowej sumiennej pracy, która niejednokrotnie pochłania więcej czasu niż zwykła szkoła. Dzieci uczęszczające jednocześnie do szkoły muzycznej muszą pogodzić ją z nauką w normalnej szkole. Wszystko to wpływa na różne aspekty rozwoju dziecka, m.in. na rozwój poznawczy poprzez naukę odmiennego materiału niż w szkole zwykłej oraz przez konieczność znalezienia przez dziecko optymalnych sposobów radzenia sobie z dużą ilością obowiązków [Wilsz 2012].

Uprawianie muzyki jest czynnością złożoną i angażuje równoczesną aktywność motoryczną, umiejętności słuchowe, operowanie symbolami, a w kolejnych etapach kształcenia także naukę harmonii, czyli określania wzajemnych zależności pomiędzy poszczególnymi tonami oraz stosowania ściśle określonych reguł. Granie na instrumencie muzycznym wymaga rozwinięcia specyficznych umiejętności, takich jak: wykonywanie precyzyjnych ruchów, odczytywanie i interpretacja zapisu nutowego oraz rozpoznawanie dźwięków i zapisywanie ich w formie symboli. Umiejętności te są odmienne, od tych wymaganych w zwykłej 
szkole. Dlatego uważa się, że muzycy posiadają inny mechanizm zachowań strategicznych od osób niegrających na instrumentach. Dzieci kształcące się w szkole muzycznej trenują wiele innych umiejętności, przez co silnie aktywują określone obszary mózgu. Taki trening może się przyczyniać do wyższych osiągnięć w wielu innych niż muzyczne dziedzinach. Niejednokrotnie dzieci uczęszczające do szkoły muzycznej uzyskują lepsze wyniki w testach umiejętności poznawczych [Wilsz 2012].

Dzięki muzyce dziecko łatwiej operuje pewnymi operacjami myślowymi, takimi jak analiza, synteza i porównywanie. Dzięki niej wyostrza się sposób poznawania świata zewnętrznego, rozwija się myślenie oraz ugruntowuje posiadana dotychczas wiedza o świecie. U dzieci aktywnie korzystających z zajęć muzycznych rozwija się zdolność koncentracji uwagi, spostrzegawczość oraz pamięć. Kształtuje się również wyobraźnia oraz postawy twórcze. Mówi się także o wpływie muzyki na szybszy rozwój intelektualny, emocjonalny, estetyczny oraz fizyczny. Granie na instrumentach muzycznych kształtuje sprawności manualne, poprawia podzielność uwagi oraz szybką orientację [Baranowska 2011].

Licznie prowadzone badania donoszą, że pobieranie lekcji gry na instrumencie przekłada się np. na umiejętności czytania, umiejętności matematyczne oraz czasowo-przestrzenne. Zdarza się, że dzieci kształcone muzycznie uzyskują lepsze wyniki także w testach integracji wizualno-motorycznej, selektywnej uwagi, pamięci werbalnej oraz pamięci operacyjnej [Wilsz 2012].

\section{Materiały i metody}

\section{Cel}

Celem niniejszej pracy było zbadanie, jak u dzieci kształcących się w szkole muzycznej rozwinięte są wyższe funkcje słuchowe, w porównaniu do dzieci bez kształcenia muzycznego. W pracy zastanowiono się także czy pomiędzy obiema grupami występują różnice w zakresie występowania trudności szkolnych.

\section{Osoby badane}

W badaniach wzięło udział 50 uczniów w wieku 8-12 lat, uczęszczających do I-V klas szkoły podstawowej. Tworzyli oni dwie grupy - badawczą oraz kontrolną.

Grupę badawczą stanowiło 25 uczniów kształcących się równocześnie w szkole muzycznej I stopnia. Wśród badanych było 16 dziewczynek oraz 9 chłopców.

Średni wiek dzieci wynosił 10,8 lat. Najmłodsze dziecko miało 8 , a najstarsze 12 lat.

Instrumenty, na jakich grają dzieci to: fortepian - dziewięcioro, skrzypce - sześcioro, gitara - czworo, perkusja dwoje, flet - dwoje, wiolonczela - jedno oraz akordeon jedno. Dzieci uczęszczają do szkoły muzycznej od 1-5 lat.

Drugą grupę, kontrolną stanowiły dzieci bez muzycznego doświadczenia, nigdy nieuczęszczające do szkoły muzycznej. Tworzyło ją tyle samo uczniów, co grupę badawczą, czyli 25 osób. Wiek badanych odpowiadał wiekowi dzieci kształconych muzycznie, czyli były to dzieci od 8 do 12 roku życia, średnia wieku 10,8 lat. Tak samo jak w grupie badawczej rozkładała się płeć badanych - było 16 dziewczynek oraz 9 chłopców.

\section{Organizacja i przebieg badań}

Spotkanie z dzieckiem trwało około 45 minut, w zależności od tempa odpowiedzi oraz indywidualnych potrzeb dziecka. Na spotkanie składały się: ustna instrukcja o celu i sposobie przeprowadzenia badań, odpowiedzenie przez dziecko na pytania ze specjalnie przygotowanej ankiety oraz przeprowadzenie testów oceny wyższych funkcji słuchowych.

Przygotowana ankieta składała się z trzech części - pierwszej związanej z danymi osobowymi, drugiej - dotyczącej muzycznego doświadczenia badanych oraz trzeciej - o trudnościach szkolnych dzieci. W przypadku grupy kontrolnej pytania z części drugiej były pomijane. Ankieta zawierała 22 pytania.

Badanie wyższych funkcji słuchowych obejmowało test oceny sekwencji tonów różniących się częstotliwością FPT, test oceny sekwencji tonów różniących się długością - DPT, test rozumienia mowy w hałasie SPN oraz test rozdzielnousznego słyszenia bez oraz $\mathrm{z}$ nachyleniem uwagi słuchowej. Wszystkie testy przeprowadzane były oddzielnie dla ucha prawego i oddzielnie dla ucha lewego. Kolejność przeprowadzania testów była jednakowa dla każdego dziecka.

Testy FPT, DPT oraz SPN pochodziły z baterii testów programu APD (Auditory Processing Disorder) autorstwa D. McPherson’a, H. Skarżyńskiego, A. Senderskiego.

Test oceny sekwencji tonów różniących się częstotliwością (FPT - Frequency Pattern Test) ma na celu zbadanie, jak pacjent radzi sobie z różnicowaniem częstotliwości dźwięków oraz jak funkcjonuje u niego krótkotrwała pamięć słuchowa. Pacjentowi podaje się trzy krótkie dźwięki, z czego dwa o innej częstotliwości niż trzeci. Badany ma powtórzyć ich sekwencje (niski-wysoki) lub określić kolejność usłyszanych bodźców. Test składał się z prezentacji 40 sekwencji dźwięków złożonych z tonów wysokich o częstotliwości $1122 \mathrm{~Hz}$ oraz niskich o częstotliwości $880 \mathrm{~Hz}$.

Test oceny sekwencji tonów różniących się długością (DPT - Duration Pattern Test) wykonywano analogicznie do testu FPT. Zadaniem pacjenta było zakomunikowanie, czy usłyszane tony były długie lub krótkie. Podawane tony różniły się długością, ton długi trwał 500 ms, a krótki 250 ms.

W celu określenie zdolności rozumienia mowy w hałasie oraz domknięcia słuchowego wykonano test rozumienia mowy w hałasie - SPN. Polega on na rozpoznawaniu słów na tle maskującego szumu, tzw. babble noise. Test ten obejmuje prezentację 5 słów w siedmiu różnych stosunkach sygnału do szumu, w zakresie od $24 \mathrm{~dB}$. Łączna suma prezentowanych sygnałów wynosi 35 słów. Poziom sygnału wynosił $50 \mathrm{~dB}$, a początkowy stosunek sygnału do szumu $24 \mathrm{~dB}$. Poziom sygnału zmieniał się o $4 \mathrm{~dB}$, 
a poziom babble noise prezentowany był na tym samym poziomie $50 \mathrm{~dB}$ SPL.

Ostatnie badanie przeprowadzono w oparciu o Test Rozdzielnousznego Słyszenia autorstwa Z. M. Kurkowskiego. Test ten jest narzędziem diagnostycznym, który ma na celu ustalenie dominacji półkuli w zakresie percepcji dźwięków mowy. Można to zrobić określając profil lateralizacji. Test Rozdzielnousznego Słyszenia składa się z dwóch ścieżek nagranych na płycie CD. Pierwszą ścieżkę tworzą 22 zestawy słów, z czego dwa z nich, to zestawy próbne. Każdy zestaw składa się z trzech wyrazów podawanych do prawego ucha oraz trzech wyrazów podawanych jednocześnie do ucha lewego. Wyniki można rozważyć w aspekcie rozwojowym odnosząc do norm wiekowych [Kurkowski 2010].

\section{Wyniki}

\section{Ankieta}

Dane zebrane podczas przeprowadzania ankiety wskazują, że długość uczęszczania dzieci do szkoły muzycznej wahała się od 1 roku do 5 lat. Wśród badanych było siedmioro dzieci uczęszczających do szkoły od roku, siedmioro od dwóch lat, dwoje od trzech, sześcioro od czterech oraz troje od pięciu lat. Wszystkie dzieci były praworęczne. Na pytania dotyczące trudności w nauce czworo uczniów przyznało się do trudności z j. polskim, dwoje $\mathrm{z}$ matematyką i czworo z j. angielskim. Żadne z dzieci nie zauważyło u siebie trudności w przedmiocie wychowanie fizyczne. Szesnaścioro dzieci nie zauważyło u siebie żadnych trudności szkolnych.

Wśród dzieci z grupy kontrolnej, tylko jedno było leworęczne, reszta praworęczna. Odpowiedzi na pytania dotyczące trudności szkolnych dały zdecydowanie gorsze wyniki, niż w grupie eksperymentalnej. Jedynie pięcioro dzieci nie zgłosiło żadnych trudności w nauce szkolnej. Wśród uczniów z trudnościami jedenaścioro wskazało na problemy z j. polskim, pięcioro na trudności z nauką matematyki oraz ośmioro z j. angielskim. Podobnie jak w grupie eksperymentalnej, żaden uczeń nie wskazał na problemy z wychowaniem fizycznym (Rycina 1).

\section{Testy centralnych funkcji słuchowych}

Wyniki testu oceny sekwencji wysokości dźwięków - FPT $\mathrm{w}$ grupie dzieci kształconych muzycznie są w większości prawidłowe. Wyniki dla ucha prawego zawierają się w przedziale $42,5-100 \%$, a dla ucha lewego w przedziale $45-100 \%$. Średni procentowy wynik w całej grupie badawczej dla ucha prawego wyniósł $87 \%$, a dla ucha lewego $84 \%$. Wynik poniżej $50 \%$ uzyskało jedno dziecko - uczennica 2 klasy, która w swobodnej rozmowie wskazała także na spore problemy z nauką w szkole muzycznej. W ankiecie dotyczącej trudności szkolnych dziewczynka zauważa $\mathrm{u}$ siebie także problemy w nauce matematyki.

Wyniki uzyskane w teście oceny sekwencji długości dźwięku - DPT w grupie badawczej okazały się jeszcze lepsze niż testu FPT. Dla prawego ucha mieszczą się w przedziale $47-100 \%$, a dla ucha lewego $65-100 \%$. Średni procentowy wynik w całej grupie badawczej dla ucha prawego wyniósł $86 \%$, a dla ucha lewego $90 \%$. Wynik poniżej 50\% uzyskało

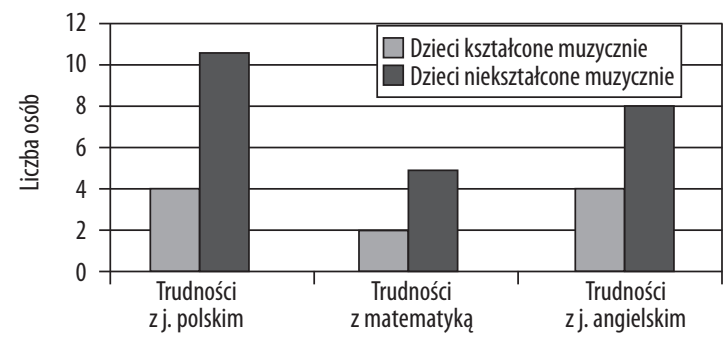

Rycina 1. Porównanie wyników ankiety dotyczącej trudności w nauce przedmiotów: j. polski, matematyka, j. angielski w dwóch grupach - dzieci kształconych i dzieci niekształconych muzycznie

jedno dziecko - uczennica pierwszej klasy. Dziewczynka w uzupełnionej ankiecie nie sugerowała żadnych problemów w nauce szkolnej.

W przypadku testu SPN uzyskano następujące wyniki: procentowy przedział poprawnych odpowiedzi zawierał się w zakresie od 22,9-54,3\% - dla ucha prawego oraz 25,7-62,9\% dla ucha lewego. 50\% poprawnych odpowiedzi osiągano w przedziale 7,3-19 dB - dla ucha prawego oraz 7,3-20,7 dB dla ucha lewego. Średni procent prawidłowych odpowiedzi dla ucha prawego dla całej grupy badawczej wynosił $38 \%$, a dla ucha lewego $44 \%$. Średnia wyników uzyskanych dla $50 \%$ poprawnych odpowiedzi wynosiła $15,62 \mathrm{~dB}$ dla ucha prawego oraz 13,72 dB dla ucha lewego.

Wyniki powyżej $18 \mathrm{~dB}$ dla $50 \%$ poprawnych odpowiedzi uzyskało czworo najmłodszych uczniów z klas I-II. Z wiekiem uczniów wzrastał procent prawidłowych odpowiedzi, a próg, przy którym osiągano 50\% poprawnych odpowiedzi malał (Tabela 1).

Wyniki uzyskane przez uczniów z grupy kontrolnej okazały się zdecydowanie niższe. W teście FPT mieściły się one w przedziale od $20-100 \%$ dla ucha prawego oraz $17,5-100 \%$ dla ucha prawego. Średni wynik dla ucha prawego wyniósł $67 \%$, a dla ucha lewego $65 \%$. Wyniki poniżej 50\% uzyskało 7 uczniów. U 71\% uczniów z problemami w omawianym teście stwierdza się jednocześnie różnego rodzaju trudności w nauce przedmiotów szkolnych (j. polski, matematyka, j. angielski).

W przypadku testu oceny sekwencji długości dźwięku DPT, uzyskane przez dzieci z grupy kontrolnej wyniki były już lepsze, niż w teście FPT. Dla ucha prawego mieściły się w przedziale 22,50-100\%, a dla ucha lewego 27,50$100 \%$. Średni wynik całej grupy kontrolnej dla ucha prawego wyniósł $78 \%$, a dla ucha lewego $81 \%$. Wyniki poniżej $50 \%$ uzyskało już tylko trzech uczniów. Tych samych troje uczniów, u których wystąpiły problemy w teście DPT, uzyskało niskie wyniki w teście FPT. Wszystkie te dzieci przyznają się jednocześnie do problemów w nauce szkolnej.

Wyniki testu SPN kształtują się podobnie jak w przypadku grupy badawczej. Procent prawidłowych odpowiedzi mieścił się w przedziale od $8,6 \%$ do $54,3 \%$ dla ucha prawego oraz w takim samym przedziale dla ucha lewego. 50\% prawidłowych odpowiedzi osiągano na progu $11-20,7 \mathrm{~dB}$ dla ucha prawego oraz 7-24 dB dla ucha lewego. Średni 
Tabela 1. Wyniki poniżej 50\% prawidłowych odpowiedzi w teście FPT lub DPT a trudności szkolne u dzieci z grupy badawczej

\begin{tabular}{lccccccccc}
\hline $\begin{array}{c}\text { Dzieci uczęszczające do szkoły } \\
\text { muzycznej }\end{array}$ & \multicolumn{2}{c}{ FPT } & \multicolumn{2}{c}{ DPT } & & \multicolumn{2}{c}{ Trudności szkolne } \\
\hline Imię dziecka & Klasa & Wiek & $\begin{array}{c}\text { Ucho } \\
\text { prawe }\end{array}$ & $\begin{array}{c}\text { Ucho } \\
\text { lewe }\end{array}$ & $\begin{array}{c}\text { Ucho } \\
\text { prawe }\end{array}$ & $\begin{array}{l}\text { Ucho } \\
\text { lewe }\end{array}$ & J. polski & Matematyka & J. angielski \\
\hline Gabriela K. & 1 & 8 & $58 \%$ & $65 \%$ & $47 \%$ & $66 \%$ & Brak & Brak & Brak \\
\hline Martyna P. & 2 & 8 & $42,5 \%$ & $45 \%$ & $60 \%$ & $85 \%$ & Brak & Występują & Brak \\
\hline
\end{tabular}

Tabela 2. Wyniki poniżej $50 \%$ prawidłowych odpowiedzi w teście FPT lub DPT a trudności szkolne u dzieci z grupy kontrolnej

\begin{tabular}{cccccccccc}
\hline \multicolumn{2}{c}{$\begin{array}{c}\text { Dzieci nieuczęszczające } \\
\text { do szkoły muzycznej }\end{array}$} & \multicolumn{2}{c}{ FPT } & \multicolumn{2}{c}{ DPT } & & Trudności szkolne \\
\hline $\begin{array}{c}\text { Imię } \\
\text { dziecka }\end{array}$ & Klasa & Wiek & $\begin{array}{c}\text { Ucho } \\
\text { prawe }\end{array}$ & $\begin{array}{c}\text { Ucho } \\
\text { lewe }\end{array}$ & $\begin{array}{c}\text { Ucho } \\
\text { prawe }\end{array}$ & $\begin{array}{c}\text { Ucho } \\
\text { lewe }\end{array}$ & J. polski & Matematyka & J. angielski \\
\hline Jakub U. & 1 & 8 & $35 \%$ & $30 \%$ & $45 \%$ & $50 \%$ & Brak & Brak & Występują \\
\hline Mateusz G. & 2 & 8 & $35 \%$ & $20 \%$ & $35 \%$ & $40 \%$ & Występują & Brak & Brak \\
\hline Karolina K. & 3 & 10 & $42,5 \%$ & $30 \%$ & $70 \%$ & $57,5 \%$ & Występują & Brak & Występują \\
\hline Julia G. & 4 & 11 & $42,5 \%$ & $60 \%$ & $95 \%$ & $95 \%$ & Brak & Brak & Brak \\
\hline Patrycja R. & 4 & 11 & $30 \%$ & $30 \%$ & $75 \%$ & $75 \%$ & Brak & Brak & Brak \\
\hline Ewelina P. & 5 & 12 & $25 \%$ & $17,5 \%$ & $70 \%$ & $82,5 \%$ & Występują & Brak & Występują \\
\hline Natalia M. & 5 & 12 & $20 \%$ & $25 \%$ & $22,5 \%$ & $27,5 \%$ & Występują & Występują & Występują \\
\hline
\end{tabular}

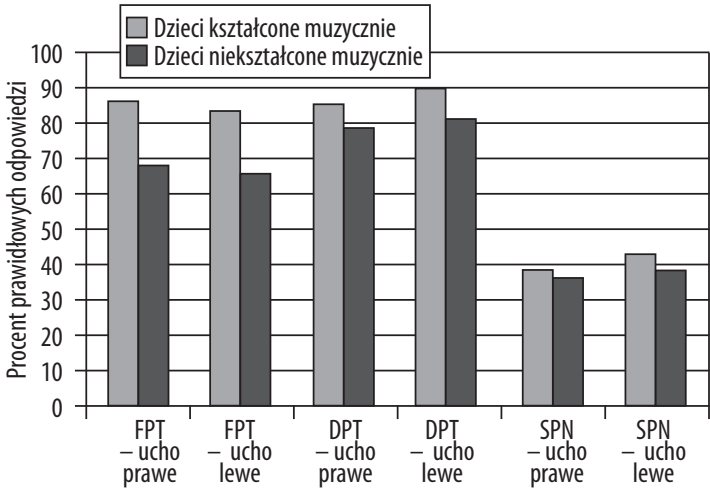

Rycina 2. Porównanie średniego procentu wyników uzyskanych w testach FPT i DPT w obu grupach

procent prawidłowych odpowiedzi wynosił $35 \%$ dla ucha prawego oraz 36,52 dla ucha lewego. Średnia wyników uzyskanych dla $50 \%$ poprawnych odpowiedzi wynosiła 15,68 dB dla ucha prawego oraz 15,13 dB dla ucha lewego (Tabela 2).

Porównując uzyskane wyniki u dzieci z grupy eksperymentalnej oraz kontrolnej można stwierdzić, że lepsze wyniki osiągnęli uczniowie z pierwszej grupy.

W teście FPT znacząco wyższe wyniki osiągali uczniowie kształcący się muzycznie. U uczniów zwykłej szkoły niejednokrotnie pojawiał się problem z rozumieniem, jaki

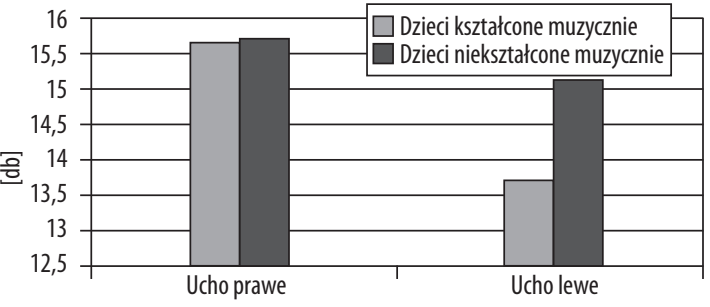

Rycina 3. Porównanie średniego progu 50\% poprawnych odpowiedzi w obu grupach

dźwięk jest niski, a jaki wysoki. U uczniów uczęszczających do szkoły muzycznej z racji ich kształcenia problem ten nie występował. Dla ucha prawego średni procent prawidłowych odpowiedzi był o $20 \%$ wyższy u dzieci z grupy badawczej, dla ucha lewego uzyskano o 19\% lepszy rezultat.

W przypadku testu DPT także wyższe wyniki osiągnęli uczniowie z grupy badawczej, chociaż w tym teście uczniowie $\mathrm{z}$ grupy kontrolnej nie mieli już tak dużych problemów, jak w przypadku testu FPT. Dzieci uczęszczające do szkoły muzycznej osiągnęły o $8 \%$ dla ucha prawego oraz o $9 \%$ dla ucha lewego.

W przypadku testu rozumienia mowy w hałasie SPN różnice pomiędzy wynikami obu grup nie są już tak widoczne. Wyższe wyniki osiągnęli uczniowie z grupy badawczej, ale już jedynie o $3 \%$ dla ucha prawego oraz $7,48 \%$ dla ucha lewego. Próg, przy którym osiągano 50\% prawidłowych 


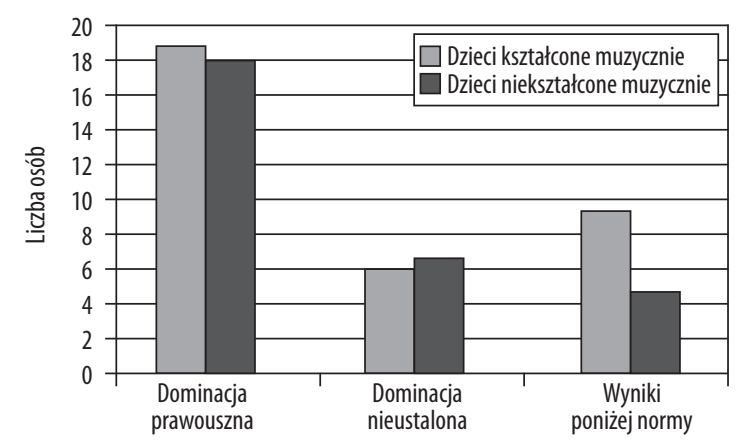

Rycina 4. Porównanie wyników testu rozdzielnousznego słyszenia w obu grupach

odpowiedzi, był niższy w przypadku grupy badawczej, o 0,06 dB dla ucha prawego oraz o $1,41 \mathrm{~dB}$ dla ucha lewego (Ryciny 2 i 3 ).

Przeprowadzenie testu rozdzielnousznego słyszenia dało następujące wyniki w grupie badawczej: u sześciorga dzieci nie stwierdzono dominacji półkulowej w zakresie percepcji dźwięków mowy, u reszty stwierdzono lateralizację prawostronną. Na uwagę zasługuje fakt, że aż dziewięcioro dzieci z badanej grupy wykazuje opóźnienia w stosunku do norm rozwojowych.

\section{Piśmiennictwo:}

1. Baranowska L.: Muzyka jako środek kształcenia dzieci. Życie Szkoły 2011; 1: 10-14

2. Czerniawska E.: O korzyściach z edukacji muzycznej płynących. Psychologia w Szkole, 2009; 4: 133-40

3. Karwowska D., Kudlik A.: Neurofizjologiczne mechanizmy odbioru i przetwarzania muzyki. W: Czerwniawska E. (red.), Muzyka i my. O różnych przejawach wpływu muzyki na człowieka. Warszawa: Difin S.A., 2012
W przypadku grupy kontrolnej u osiemnaściorga dzieci stwierdzono przewagą ucha prawego, u siedmiorga nie stwierdzono przewagi żadnego ucha, a opóźnienie w stosunku do norm rozwojowych wykazuje pięcioro dzieci.

Porównując wyniki uzyskane w teście rozdzielnousznego słyszenia w obu grupach, należy zauważyć, że wyniki kształtują się podobnie. W obu grupach u wszystkich dzieci z ustaloną dominacją stwierdzono dominację ucha prawego. Także u podobnej liczby dzieci nie stwierdzono przewagi ucha oraz podobnie $\mathrm{w}$ obu grupach występowały opóźnienia w odniesieniu do norm rozwojowych.

\section{Podsumowanie}

Lepsze wyniki w testach oceniających umiejętność przetwarzania dźwięków uzyskały dzieci uczęszczające do szkoły muzycznej od dzieci niekształconych muzycznie. Oznacza to, że ich zdolności percepcyjne w zakresie wyższych procesów przetwarzania słuchowego, osiągają lepszy poziom. Różnic nie zauważono w teście rozdzielnousznego słyszenia. Wyniki w obu grupach prezentowały się podobnie. Analiza zebranego materiału dotyczącego trudności szkolnych również skłania ku twierdzeniu, że problemy w nauce w mniejszej mierze występują u dzieci uczęszczających jednocześnie do szkoły muzycznej, niż u dzieci nieuczęszczających. Na podstawie przeprowadzonych badań można zatem uznać, że uczniowie pobierający naukę muzyczną mają lepiej wykształcone wyższe funkcje słuchowe oraz osiągają lepsze wyniki w nauce szkolnej.
4. Krukow P.: Muzyka i mózg. Muzyka, 2003; 21 9(38)

5. Kurkowski Z.M.: Test rozdzielnousznego słyszenia - podręcznik użytkownika. Lublin, 2010

6. Sacks O.: Muzykofilia. Opowieści o muzyce i mózgu. Poznań: Zysk i S-ka Wydawnictwo, 2009

7. Wilsz N.: Czy uprawianie muzyki ma korzystny wpływ na procesy poznawcze, strategie uczenia się i osiągnięcia w nauce? W: Czerniawska E. (red.), Muzyka i my. O różnych przejawach wpływu muzyki na człowieka. Warszawa: Difin S.A., 2012 